\title{
A New Kakanui Hornblende for Use by EPMA Labs
}

John Fournelle ${ }^{1}$, Karsten Goemann ${ }^{2}$ and Anette von der Handt ${ }^{3}$

${ }^{1}$ University of Wisconsin, Madison, Madison, Wisconsin, United States, ${ }^{2}$ University of Tasmania, Hobart, Tasmania, Australia, ${ }^{3}$ University of Minnesota, Minneapolis, Minnesota, United States

Most electron microprobe analysis (EPMA) labs, particularly ones working with geological materials, have mineral and glass standards from the Smithsonian Institution National Museum of Natural History (NMNH) [1]. They were developed between 1968-78 to fill the need for geologists using electron microprobes to study terrestrial and extraterrestrial samples [2]. Gene Jarosewich, Joe Nelen, and Julie Norberg applied their skills as classical wet chemists to accurately determine the chemistry of various minerals and glasses which, after first being crushed, sieved and separated by heavy liquids and magnetic susceptibility, were then tested by microprobe, for inter-grain homogeneity. Gene was very clear about the limitations of the standards, that X-ray counts should be acquired from multiple grains, as the stated wet chemical compositions represented averages of a large number of small of grains: "a reasonably large number of counts on a reasonably large number of grains" needed to be acquired on these standards.

Well known are the NMNH "Kakanui" mineral standards, fragments from crushed megacrysts in Oligocene tuff in the South Island of New Zealand [3], [4]. Additionally, in the late 1980s, researchers at Otago University similarly evaluated minerals from the Kakanui outcrop as EPMA standards [5] [6].The Kakanui hornblende/kaersutite (USNM 143965) is valued by many EPMA labs, as it contains many of the key elements present in common minerals ( $\mathrm{Na}, \mathrm{Mg}, \mathrm{Al}, \mathrm{Si}, \mathrm{K}, \mathrm{Ca}, \mathrm{Ti}, \mathrm{Fe}, \mathrm{O}$ ), in sufficient abundances to make both a peaking material and a quality control material (e.g., as a secondary standard). There are three issues though: there is a small amount of variability between grains (potentially different composition from published value), the grains are small and can be lost after several mount repolishings, and many grains contain small melt/crystal/vapor inclusions-which were not noticable 4 decades ago, but with todays field emission instruments, are clearly visible [7].

Megacrysts of Kakanui hornblende are present in the hylocastite host material, and in 2017 Fournelle collected Kakanui North Head outcrop samples [8], one including a 3-4 cm wide hornblende crystal. It easily fractured into 3-5 mm fragments, and several of these have been distributed to other EPMA labs for evaluation as to the homogeneity of each fragment and possible use as reference materials. These large fragments are available for distribution, and interested EPMA labs should contact the first author for a piece for evaluation.

Reported here in Table 1 are the EPMA compositions of different fragments by three different EPMA labs, using a range of techniques (i.e., standards, background method, matrix correction). All were acquired at $15 \mathrm{kV}$, with 20-30 nA and a defocused beam, on FE electron probes. Also shown in Table 1 are the published compositions of the Smithsonian and two other Kakanui hornblendes developed as standards by researchers at the University of Otago.

Each lab measured compositions from 50-70 locations on either one large fragment (UW, UT), or 10 locations on 5 fragments (UM). Looking at the size of the standard deviation of the elements for each lab, two of the labs (UT, UM) found a high degree of homogeneity on their fragments, whereas one (UW) lab's values showed a somewhat larger variation. Comparing the compositions beween all labs, there was a small degree of variation for the major elements $\mathrm{Si}, \mathrm{Ca}, \mathrm{Fe}$ and minor elements $\mathrm{Ti}$ and $\mathrm{K}$. Values ranged wider for $\mathrm{Mg}$ (2.5\% max variation) and $\mathrm{Al}$ (3.5\% max variation), with a wider variation for $\mathrm{Na}$. 
Comparing the compositions determined here for 7 fragments of the 2017 North Head with the original Jarosewich values, there clearly are signifcant differences in the compositions for $\mathrm{Mg}$ and $\mathrm{Fe}$, whereas $\mathrm{Al}$ is quite similar. Another significant benefit is that, so far, the fragments do not contain the small micronsize inclusions which many/most of the USNM 143965 contain (see Figure 1). Some A fragment surfaces have a thin white deposit (zeolite?), which may be visible if sufficient grinding hasn't been done.

These fragments are being made available to the EPMA community, to evaluate as possible secondary standards. Further information will be available when other labs have been able to test them [9].

\begin{tabular}{|c|c|c|c|c|c|c|c|c|c|}
\hline & New & New & New & New & New & New & 1980 & 1989 & 1989 \\
\hline & UW-MSN & UW-MSN & U Tasmania & U Tasmania & UM-Minn. & UM-Minn. & Smithsonian & Reay et al & Reay et al \\
\hline & 1 fragment & 1 fragment & 1 fragment & 1 fragment & 5 fragments & 5 fragments & Jarosewich+ & Geostds NL & Geostds NL \\
\hline & 61 spots & 61 spots & 70 spots & 70 spots & 50 spots & 50 spots & Wet Chem & XRF & XRF \\
\hline & Average & Std Dev & Average & Std Dev & Average & Std Dev & Average & KK1 & KK2 \\
\hline $\mathrm{SiO} 2$ & 40.29 & 0.41 & 40.05 & 0.10 & 40.09 & 0.15 & 40.37 & 40.33 & 40.55 \\
\hline $\mathrm{TiO} 2$ & 4.97 & 0.09 & 4.95 & 0.02 & 4.87 & 0.03 & 4.72 & 5.75 & 4.91 \\
\hline $\mathrm{Al} 2 \mathrm{O} 3$ & 15.33 & 0.11 & 14.81 & 0.05 & 15.10 & 0.04 & 14.90 & 14.63 & 14.96 \\
\hline $\mathrm{MgO}$ & 13.33 & 0.14 & 13.48 & 0.05 & 13.14 & 0.08 & 12.80 & 13.22 & 13.60 \\
\hline $\mathrm{FeO}^{*}$ & 9.20 & 0.15 & 9.29 & 0.07 & 9.36 & 0.07 & 10.92 & 9.61 & 9.56 \\
\hline $\mathrm{MnO}$ & & & 0.08 & 0.01 & 0.07 & 0.01 & 0.09 & 0.06 & 0.08 \\
\hline $\mathrm{CaO}$ & 10.16 & 0.11 & 10.20 & 0.03 & 10.12 & 0.04 & 10.30 & 10.03 & 10.27 \\
\hline $\mathrm{Na} 2 \mathrm{O}$ & 2.39 & 0.06 & 2.43 & 0.02 & 2.62 & 0.02 & 2.60 & 2.57 & 2.44 \\
\hline $\mathrm{K} 2 \mathrm{O}$ & 2.15 & 0.04 & 2.14 & 0.02 & 2.11 & 0.02 & 2.05 & 2.12 & 2.22 \\
\hline Total & 97.83 & & 97.42 & & 97.48 & & 98.75 & 98.32 & 98.59 \\
\hline & & & & & & & & & \\
\hline kV & $15 \mathrm{kV}$ & & $15 \mathrm{kV}$ & & $15 \mathrm{kV}$ & & & rutile & typo in \\
\hline $\mathrm{nA}$ & $20 \mathrm{nA}$ & & $20 n A$ & & $30 \mathrm{nA}$ & & & inclusions & original $\mathrm{Na} 2 \mathrm{O}$ \\
\hline beam size & $10 \mathrm{um}$ & & 10 um & & 5 um & & & & \\
\hline backgrnds & MAN & & off peak & & MAN & & & & \\
\hline $\mathrm{ZAF} / \mathrm{prZ}$ & ArmstrongLS & & ArmstrongLS & & PAP fuil & & & & \\
\hline MACs & Linemu Henke & & Linemu Henke & & FFAST & & & & \\
\hline Instrument & SXFive FE & & 8530 & & 8530 & & & & \\
\hline
\end{tabular}

Figure 1. Table 1. Comparison of WDS EPMA measurements of the new, 2017 Kakanui Hornblende by 3 electron probes, and original published values for the Smithsonian USNM 143965 and also values from Reay et al. 


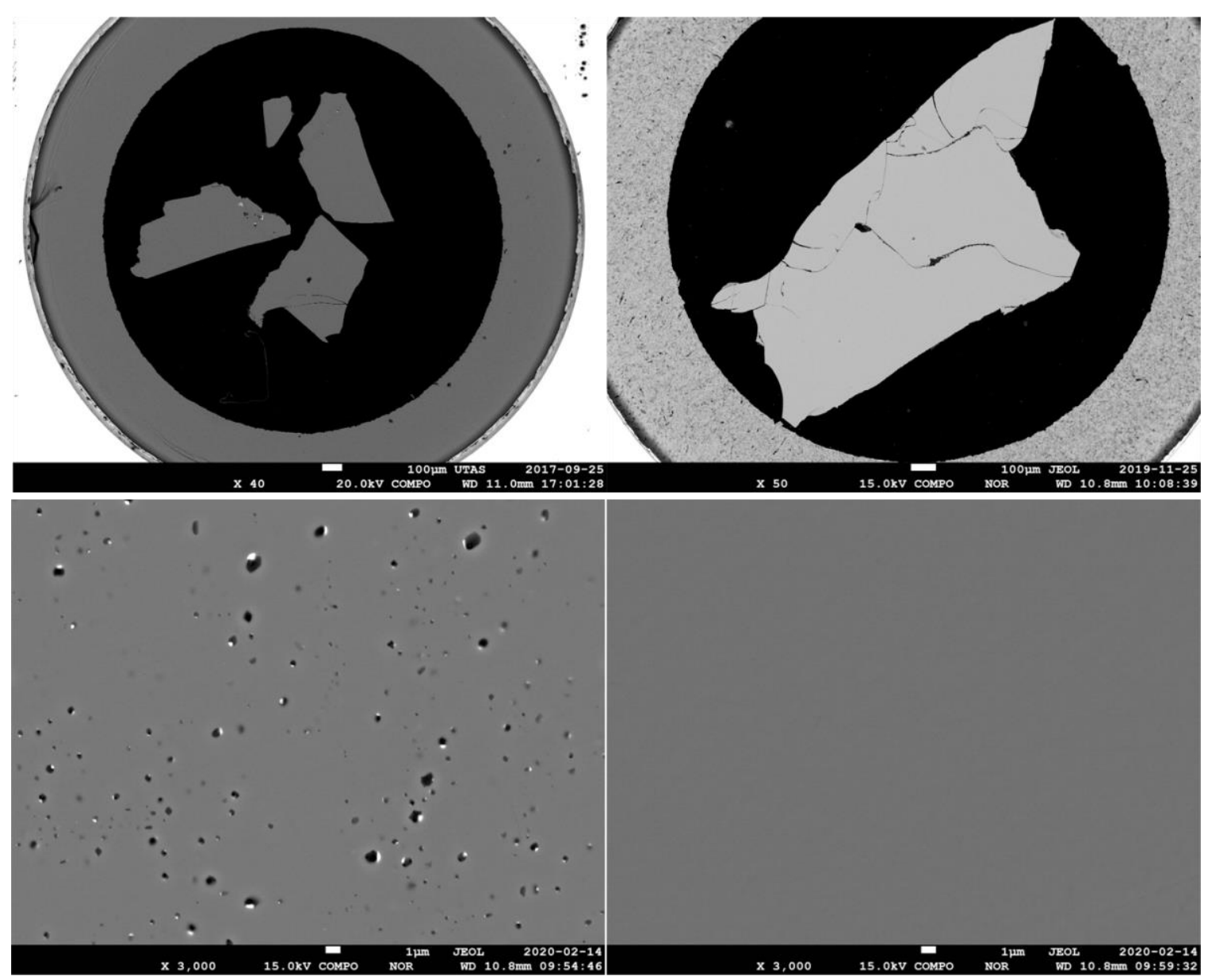

Figure 2. Figure 1. Top Left: 3 fragments of Smithsonian Kakanui hornblende (USNM 143965); Top Right: 2017 Kakanui hornblende fragment at similar magnfication.Bottom Left: Ubiquitous micron and sub-micron inclusions in a fragment of USNM 143965.Bottom Right: No inclusions in 2017 Kakanui hornblende fragment.

\section{References}

[1] E Jarosewich, JA Nelen and JA Norberg, Geostandards Newsletter, 4(1) (1980), p. 43-47.

[2] E Jarosewich, Journal of Research of the National Institute of Standards and Technology, 107(6) (2002), p. 681-685. (A history of the development of the Smithsonian microbeam stds)

[3] B Mason, New Zealand Journal of Geology and Geophysics, 9:4 (1966), p. 474-480.

[4] B Mason, Contributions to Mineralogy and Petrology, 19(4) (1968), p. 316-327.

[5] A Reay, RD Johnstone and Y Kawachi, Geostandards Newsletter, 13(1) (1989), p. 187-190.

[6] A Reay, RD Johnstone and Y Kawachi, Geostandards Newsletter, 17(1) (1993), p. 135-136.

[7] EP Vicenzi and TR Rose, Microscopy and Microanalysis, 14(S2) (2008), p. 522-523.

[8] J Fournelle and J Scott, Microscopy and Microanalysis 23.S1 (2017): 502-503.

[9] Support for this research came from the National Science Foundation: EAR-1337156 (JHF), EAR1554269 (JHF) and EAR-1849386 (JHF), 